\title{
Peningkatan Hasil Belajar IPA-Fisika Melalui Pendekatan Deep Dialogue dan Critical Thingking pada Siswa Kelas VII-C SMP Negeri 2 Biromaru
}

\author{
Hizrah, I Wayan Darmadi, I Komang Werdhiana \\ Email: Hizrahfisika@yahoo.com \\ Prodi Pendidikan Fisika, Jurusan Pendidikan MIPA \\ Jl. Soekarno Hatta KM.9 Kampus Bumi Tadulako Tondo Palu - Sulawesi Tengah
}

\begin{abstract}
Abstrak - Penyebab hasil belajar IPA fisika siswa kelas VIIC SMP Negeri 2 Biromaru rendah, karena metode pembelajaran yang diterapkan belum efektif. Salah satu upaya untuk meningkatkan hasil belajar IPA fisika siswa dalam proses pembelajaran adalah dengan menerapkan metode pembelajaran pendekatan Deep Dialogue dan Critical Thinking. Penelitian ini merupakan penelitian tindakan kelas (PTK) pada siswa kelas VIIc SMP Negeri 2 Biromaru yang berjumlah 23 orang siswa. Penelitian tindakan kelas ini dilakukan dalam dua siklus dengan materi besaran dan Pengukuran. Data diperoleh melalui lembar observasi aktifitas guru dan aktifitas siswa, serta tes hasil tindakan. Hasil penelitian menunjukkan bahwa aktifitas guru dan siswa mengalami peningkatan yang signifikan dari siklus I ke siklus II dan berada dalam kategori baik. Berdasarkan analisis hasil belajar diperoleh data siswa siklus I ke siklus II mengalami peningkatan sebesar $11,35 \%$, dimana nilai daya serap klasikal siklus I sebesar $67,13 \%$, dan siklus II sebesar $75,73 \%$. Untuk ketuntasan belajar klasikal meningkat sebesar $21,06 \%$ dengan nilai ketuntasan klasikal siklus I adalah $65,21 \%$ dan siklus II sebesar $82,61 \%$. Berdasarkan indikator keberhasilan yakni apabila persentase daya serap klasikal $80 \%$ dan ketuntasan klasikal 80\%, disimpulkan bahwa metode pendekatan Deep Dialogue dan Critical Thinking dapat meningkatkan hasil belajar IPA fisika siswa kelas VIIC SMP Negeri 2 Biromaru.
\end{abstract}

Kata Kunci : Deep Dialogue, Critical Thingking, Hasil Bealajar

\section{PENDAHULUAN}

Penguasaan konsep-konsep fisika sangat bergantung pada pengalaman belajar siswa yang diperoleh selama proses pembelajaran berlangsung. Untuk itulah diperlukan suatu strategi pembelajaran yang sesuai dalam mencapai keberhasilan proses belajarmengajar. Dalam hal ini guru memiliki peranan penting, karena gurulah yang menentukan tujuan pembelajaran, memilih dan menggunakan media pembelajaran serta memilih dan menggunakan sumber pembelajaran yang sesuai. Agar tujuan pembelajaran dapat tercapai, maka harus ada interaksi yang baik antara guru dan siswa.

Kurangnya memberikan keterampilan berpikir kritis dalam proses pembelajaran dapat mengarahkan siswa pada kebiasaan melakukan berbagai kegiatan tanpa mengetahui tujuan dan mengapa mereka melakukannya. Sementara yang terjadi dibanyak sekolah selama ini lebih menekankan kepada belajar informasi dan isi/materi daripada kemampuan berpikir dan pemahaman konsepnya. Padahal didalam proses pembelajaran di era global yang penuh dengan tantangan dan perubahan yang serba cepat terjadi sekarang ini, siswa membutuhkan keterampilan mengembangkan konsep berpikir kritis. Pada dasarnya kebutuhan terhadap pengembangan kemampuan berpikir ditandai oleh pertumbuhan yang mengacu pada berpikir kritis dan inovatif.

Berdasarkan hasil observasi pada SMP Negeri 2 Biromaru di kelas VII pada pelajaran IPA fisika masih rendah, karena belum memenuhi Kriteria Ketuntasan 


\section{Jurnal Pendidikan Fisika Tadulako (JPFT) \\ Vol. 1 No. 3 \\ ISSN 23383240}

Minimal (KKM) untuk pelajaran IPA Fisika adalah 75. Hal ini nampak dari data nilai hasil pembelajaran semester ganjil dan genap mata pelajaran IPA Fisika pada tahun ajaran 2010/2011 dan 2011/2012 seperti pada Tabel 1.

Tabel 1 Nilai IPA-Fisika Siswa Kelas VII SMP Negeri 2 Biromaru.

\begin{tabular}{|c|c|c|c|c|}
\hline \multirow{2}{*}{ No } & \multirow{2}{*}{\begin{tabular}{c} 
Tahun \\
Ajaran / \\
\cline { 3 - 5 }
\end{tabular}} & \multicolumn{3}{|c|}{ Nilai Rata-Rata Kelas } \\
\cline { 3 - 5 } & Kemester & $\mathrm{A}$ & $\begin{array}{c}\text { Kelas } \\
\mathrm{B}\end{array}$ & $\begin{array}{c}\text { Kelas } \\
\text { C }\end{array}$ \\
\hline 2 & $\begin{array}{c}2010 / 2011 \\
\text { Ganjil } \\
\text { Genap }\end{array}$ & $\begin{array}{c}69,74 \\
73,45\end{array}$ & $\begin{array}{c}66,50 \\
73,08\end{array}$ & $\begin{array}{c}59,08 \\
70,31\end{array}$ \\
\hline 2 & $\begin{array}{c}2011 / 2012 \\
\text { Ganjil }\end{array}$ & 70,88 & 65,50 & 65,07 \\
\hline
\end{tabular}

Sumber: SMP Negeri 2 Biromaru

Berdasarkan data Tabel 1, terlihat bahwa hasil belajar siswa mata pelajaran fisika masih belum memenuhi KKM. Salah satu upaya untuk meningkatkan KKM dalam proses pembelajaran yaitu memberikan kesempatan pada siswa untuk lebih aktif dan bekerja sama dengan siswa lain serta untuk meningkatkan hasil belajar siswa adalah dengan penerapan pendekatan pembelajaran Deep Dialogue dan Critical Thinking.

Proses belajar-mengajar adalah proses dialog. Sebagai proses dialog, praktik pembelajaran memerlukan prasyarat kesiapan fisik dan mental pelaku penyampai pesan dan penerima pesan pembelajaran. Pembelajaran berbasis Deep Dialogue dan Critical Thinking mengakses paham konstruktivisme dengan menekankan adanya dialog mendalam dan berpikir kritis. Dengan kegiatan berpikir kritis, siswa dapat melakukan pemikiran yang jernih dan kritis, membagi rasa, saling mengasihi sehingga perbedaan pendapat dan pandangan yang ada dapat dipecahkan dan dicerahkan dengan dialog terbuka. Selain itu, dengan dialog mendalam dan berpikir kritis, siswa akan belajar mengenal dunia lain di luar dunia dirinya dan selanjutnya mampu menghargai perbedaan-perbedaan yang ada di tengah-tengah masyarakat.

\section{METODOLOGI}

Penelitian ini adalah penelitian tindakan kelas. Pelaksanan penelitian ini meliputi dua tahap yang tiap tahapnya disebut siklus. Penelitian ini terdiri dari 2 siklus, masing masing siklus yang terdiri dari 6 tahap, yaitu refleksi awal, perencanaan, pelaksanaan tindakan, observasi, evaluasi, dan refleksi. Adapun tahap pelaksanaan penelitian tindakan kelas ini mengacu pada desain yang dikemukakan oleh Kemmis dan Mc. Taggart (Depdiknas, 2003:19)

Subjek penelitian adalah siswa kelas $\mathrm{VII}_{\mathrm{C}}$ yang mengikuti mata pelajaran IPA Fisika tahun ajaran 2013/2014, dengan jumlah siswa 23 orang yang terdiri dari 7 orang siswa laki - laki dan 16 orang siswa perempuan. Data yang dikumpulkan dalam penelitian ini adalah hasil belajar siswa dalam mengerjakan soal-soal fisika yang diberikan melalui tes akhir pada setiap tindakan dan hasil observasi yang memuat catatan mengenai kegiatan pembelajaran, baik aktivitas yang berkaitan dengan guru (peneliti) maupun yang berkaitan dengan siswa, serta hasil belajar siswa.

Pada pembelajaran siklus I dilakukan dengan membagi siswa dalam 5 kelompok, setiap kelompok terdiri dari 5-6 orang. Siswa dibagikan LKS untuk dikerjakan secara berkelompok, mendiskusikan dan mempresentasekan di depan kelas.

Pelaksanaan tindakan pada siklus I dilaksanakan mengacu pada perencanaan tindakan siklus I yang terdiri dari skenario pembelajaran yang telah disusun kemudian penyajian materi yang dilaksanakan sebanyak 2 kali pertemuan, setiap kali pertemuan atau tatap muka dilakukan pengisian lembar observasi siswa, guru dan evaluasi proses siswa pada saat KBM berlangsung oleh observer. Kemudian pada akhir pelaksanaan siklus dilakukan evaluasi terhadap siswa guna mengetahui hasil belajar atau kemampuan siswa. Dan Analisis data dilakukan dengan menghitung (DSK, KBK) pada setiap siklus

\section{HASIL DAN PEMBAHASAN}

Hasil yang didapatkan dari pengamatan atau observasi yang dilakukan dalam KBM pada setiap pertemuan pada siklus I adalah untuk aktivitas guru pada pertemuan 1 adalah 70,73\%, sedangkan pada pertemuan 2 adalah $81,25 \%$, diperoleh, rata-rata adalah $75,78 \%$ berada pada kategori cukup. Aktivitas siswa pada siklus I pertemuan 1 adalah 62,5\%, untuk pertemuan 2 adalah $71 \%$ diperoleh, ratarata $66,75 \%$ berada pada kategori kurang.

Adapun hasil yang diperoleh untuk daya serap klasikal (DSK) dan ketuntasan belajar 


\section{Jurnal Pendidikan Fisika Tadulako (JPFT) \\ Vol. 1 No. 3 \\ ISSN 23383240}

klasikal (KBK) ditunjukan pada tabel 3.1 dibawah ini:

Tabel 2 Hasil daya serap klasikal dan ketuntasan klasikal siklus I

\begin{tabular}{|c|l|c|}
\hline No & \multicolumn{1}{|c|}{ Aspek } & Pencapaian \\
\hline 1 & Daya serap klasikal & $67,13 \%$ \\
\hline 2 & $\begin{array}{l}\text { Ketuntasan belajar } \\
\text { klasikal }\end{array}$ & $65,21 \%$ \\
\multicolumn{2}{|c|}{ hasil kegiatan } \\
\hline \multicolumn{2}{|c|}{ Berdasarkan }
\end{tabular}

pembelajaran, maka dapat diperoleh

kekurangna dari siklus I yaitu :

1. Sebagaian siswa belum memperhatikan penjelasan materi yang disampaikan oleh guru.

2. Sebagian siswa masih ada yang raguragu untuk bertanya dan menjawab pertanyaan yang terkait dengan materi yang dibahas.

3. Kurangnya kerja sama atau diskusi kelompok.

4. Masih ada sebagian siswa yang kurang mampu dalam menyimpulkan.

Refleksi tindakan dilakukan guru guna mencari kekurangan dari pembelajaran siklus I, dan merekomendasikan kekurangan untuk diperbaiki pada siklus II. Pada dasarnya kegiatan yang dilakukan pada siklus II sama dengan kegiatan yang dilakukan pada siklus I. Pada hasil belajar siswa untuk siklus II diketahui bahwa hasil yang diperoleh sudah memenuhi indikator keberhasilan kuantitatif dengan ketuntasan klasikal sebesar $82,61 \%$ dan daya serap klasikal sebesar 75,73\%.

Untuk Aktivitas guru pada siklus II dari pertemuan I dan pertemuan II masing masing sebesar $85,93 \%$ dan $92,18 \%$ diperoleh, rata-rata keseluruhan aktivitas guru sebesar $89,06 \%$ berada pada kategori baik. Sedangkan untuk aktivitas siswa dengan jumlah rata - rata keseluruhan dari pertemuan I dan II sebesar $86,45 \%$ berada pada kategori baik.

Penerapan pendekatan Deep Dialogue dan Critical Thingking dalam pembelajaran merupakan suatu strategi mengajar yang lebih mengarahkan siswa kepada proses keterlibatan siswa secara langsung di dalam kegiatan pembelajarannya. Dengan model pembelajaran DD/CT yang diterapkan dalam penelitian ini dapat meningkatkan aktivitas dan hasil belajar siswa. Terlihat adanya perubahan sebelum dilaksanakan tindakan dan sesudah tindakan. Sebelum pemberian tindakan atau saat pemberian tes awal hasilnya menunjukkan terdapat 13 orang siswa yang tidak tuntas, dan setelah diberikan tindakan pada siklus I banyaknya siswa yang tidak tuntas berkurang menjadi 8 orang siswa.

Untuk Peningkatan aktivitas guru pada siklus I dari pertemuan pertama dan pertemuan ke dua masing - masing sebesar $70,31 \%$ dan $81,25 \%$ diperoleh jumlah rata - rata keseluruhan aktivitas guru sebesar $75,78 \%$ berada pada kategori cukup. Dan untuk siklus II dari pertemuan pertama dan pertemuan ke dua masing masing sebesar $85,93 \%$ dan $92,18 \%$ diperoleh jumlah rata-rata keseluruhan aktivitas guru sebesar $89,06 \%$ berada pada kategori baik. Selama kegiatan pembelajaran tiap siklus, diperoleh peningkatan sebesar $17,52 \%$.

Pada aktivitas siswa pada siklus I dari pertemuan pertama dan pertemuan ke dua sebesar $62,5 \%$ dan $71 \%$ diperoleh Jumlah rata-rata sebesar $66,75 \%$ berada pada kategori kurang dan pada siklus II pertemun pertama sebesar $81,25 \%$ dan pertemuan ke dua $91,66 \%$ diperoleh jumlah rata - rata keseluruhan dari pertemuan pertama dan kedua sebesar $86,45 \%$, maka terjadi peningkatan aktivitas siswa sebesar $29,51 \%$.

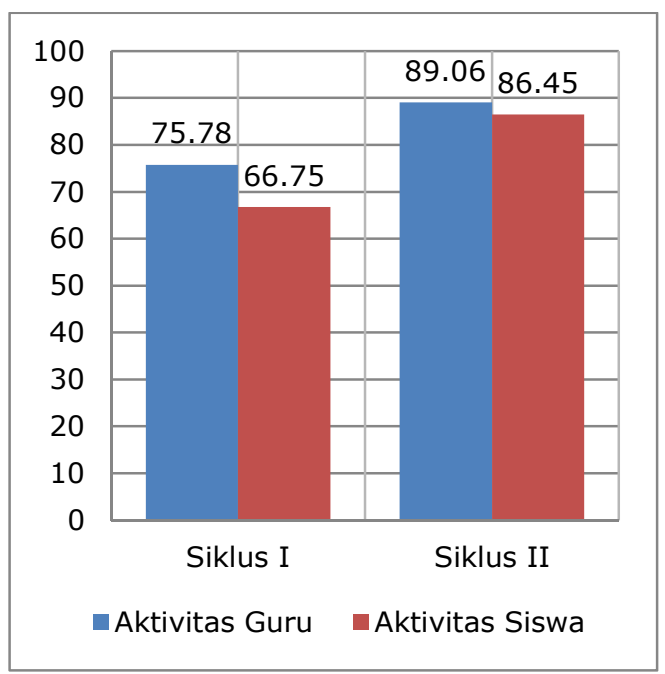

Gambar 1 Grafik Peningkatan Aktifitas Guru dan Siswa

Pada setiap tahap pembelajaran peran guru sangat berpengaruh terhadap peningkatan aktivitas siswa dalam memahami materi IPA fisika. Guru berusaha mempehatikan masalah-masalah 


\section{Jurnal Pendidikan Fisika Tadulako (JPFT) \\ Vol. 1 No. 3 \\ ISSN 23383240}

yang dihadapi oleh siswa pada saat melaksanakan pembelajaran dan berusaha mendorong siswa agar mampu mengungkapkan ide-ide mereka dan membangun konsep fisika melalui pembelajaran. Guru juga berusaha memotivasi siswa agar lebih aktif dalam melakukan kegiatan pembelajaran karena dari pelaksanaan kegiatan ini mereka diharapkan lebih aktif dalam mencari dan memahami materi fisika yang diajarkan. Dari Gambar 4.1 tersebut terlihat terjadi peningkatan aktifitas guru dan siswa dari siklus I ke siklus II.

Peningkatan Hasil Belajar Fisika Siswa dijelaskan sebagai berikut: berhasilnya penelitian ini ditunjukkan pada peningkatan hasil belajar fisika siswa dari siklus I ke siklus II, terlihat dari ketuntasan klasikal yang diperoleh pada siklus I yaitu $65,21 \%$ dimana masih terdapat 8 orang siswa yang belum tuntas sedangkan ketuntasan klasikal pada siklus II yaitu $82,61 \%$ dimana terdapat 4 orang siswa yang belum tuntas, diperoleh peningkatan sebesar 26,68\%. Selain itu, diketahui pula bahwa peningkatan daya serap klasikal dari siklus I ke siklus II, dimana daya serap klasikal pada siklus I sebesar $67,13 \%$ dan daya serap klasikal pada siklus II sebesar $75,73 \%$ diperoleh peningkatan sebesar $12,81 \%$.

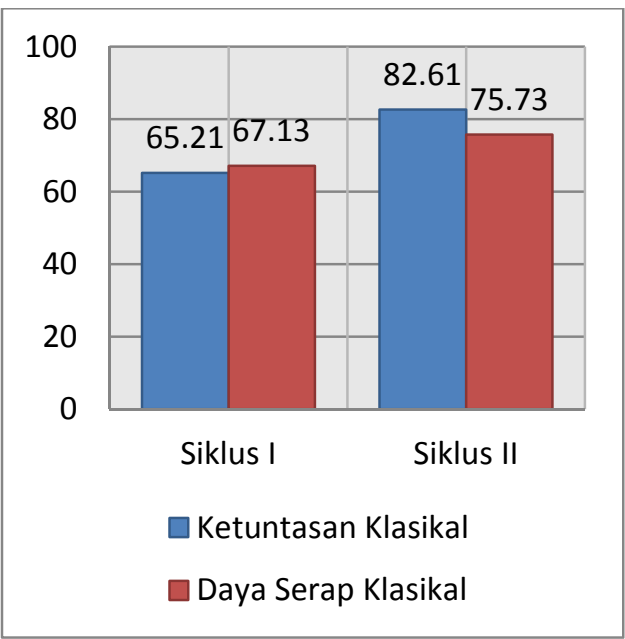

Gambar 2 Grafik Peningkatan Hasil Belajar IPA Fisika Siswa Siklus I dan Siklus II

Beberapa prinsip yang harus dikembangkan dalam deep dialogue/critical thinking antara lain adanya komunikasi dua arah, prinsip saling memberi yang terbaik, menjalin hubungan kesederajatan dan keberadaban, serta empatisitas yang tinggi.
Dengan demikian, deep dialogue/critical thinking mengandung nilai-nilai demokrasi dan etis, sehingga keduanya dapat dimiliki oleh siswa, selain pemahaman terhadap materi pembelajaran itu sendiri. Bagaimana pengaruh penggunaan strategi deep dialogue/CT terhadap pemahaman materi pembelajaran dibandingkan dengan penggunaan strategi yang melalui ceramah, presentasi dan tanyajawab kaitannya dengan kemampuan awal siswa, akan dicari jawabannya dalam penelitian ini.

Berdasarkan uraian di atas, diperoleh bahwa pendekatan Deep Dialogue dan Critical Thingking dalam pembelajaran dapat meningkatkan aktivitas dan hasil belajar IPA fisika pada siswa kelas VIIC SMP Negeri 2 Biromaru.

\section{KESIMPULAN DAN SARAN}

\section{Kesimpulan}

Berdasarkan hasil penelitian dan analisis penelitian tindakan kelas diperoleh kesimpulan bahwa penerapan pendekatan Deep Dialogue dan Critical Thingking dapat meningkatkan hasil belajar siswa VII SMP Negeri 2 Biromaru. Peningkatan hasil belajar siswa dari siklus I ke siklus II, diperoleh sebesar 26,68\%. Peningkatan daya serap klasikal dari siklus I ke siklus II, diperoleh sebesar 12,81\%.

\section{Saran - saran}

Sesuai dengan hasil penelitian dan analisa data serta kesimpulan, maka peneliti menyarankan :

1. Agar guru mata pelajaran fisika hendaknya menerapkan pendekatan Deep Dialogue dan Critical Thingking (DD/CT) untuk meningkatkan hasil belajar siswa.

2. Diharapkan kepada peneliti selanjutnya agar dapat memperhatikan analisis latar kultural/budaya dan intelegensi siswa sebelum pembentukan kelompok.

\section{DAFTAR PUSTAKA}

[1] Arthana. Ketut $P$, "Pembelajaran Inovatif Berbasis Deep Dialogue/Critical Thinking", Jurnal Tekhnologi Pendidikan, Vol.10, No. 1, April 2010, h. 20. 


\section{Jurnal Pendidikan Fisika Tadulako (JPFT) \\ Vol. 1 No. 3}

ISSN 23383240

[2] Budiningsih C. Asri. Pengaruh Pembelajaran Deep Dialogue dan Kemampuan Awal Terhadap Pemahaman Materi Kuliah, "Jurnal Penelitian IImu Pendidikan.Vol.3,No.2,September 2010.

[3] Depdiknas. 2003. Penilaian Tindakan Kelas. Jakarta: Departemen Pendidikan Nasional.

[4] Global Dialogue Institute. 2001. Deep Dialogue/Critical Thinking as Instructional Approach. Disajikan pada TOT Pendidikan Anak Seutuhnya di Malang 1-11 Juli 2001. 